\title{
Caminhos por Cabo Verde, com Benilde Justo Caniato
}

of buscarmos as referências acadêmicas sobre Cabo Verde no Brasil, notamos como vem sendo primordial a atuação da Profa. Dra. Benilde Justo Caniato, da Universidade de São Paulo. Ao longo de sua carreira em pesquisa e docência a professora tem dirigido grande atenção a vários aspectos da literatura, língua, cultura e sociedade cabo-verdianas. Atualmente professora de Pós-graduação da Área de Estudos Comparados de Literaturas de Língua Portuguesa da FFLCH/USP, Benilde Caniato publicou em 2005 pela Ateliê Editorial o livro Percursos pela Africa e por Macau, em que vários dos ensaios se referem a Cabo Verde. Além disso, tem publicado vários artigos e trabalhos sobre o assunto no Brasil e no exterior, além de se destacar como orientadora de numerosos trabalhos sobre Cabo Verde. A professora nos recebeu para uma longa e iluminadora conversa em que se entrelaçaram informações sobre Cabo Verde, cultura e literatura cabo-verdianas com o seu próprio percurso acadêmico. Ao final, a professora sugeriu o título que demos a esta entrevista: Caminhos por Cabo Verde.

Débora Leite David e Susanna Ventura 
R.V.A. - A partir de quando a senhora iniciou seu trabalho de pesquisa sobre Cabo Verde?

Desde 1979 tenho me dedicado a pesquisar sobre o Arquipélago de Cabo Verde: história, língua portuguesa, crioulo e literatura. Enquanto fui professora do curso de graduação da disciplina Filologia e Língua Portuguesa, procurei desenvolver com meus alunos temas que abordassem a língua portuguesa no mundo. Em Cabo Verde, especialmente, buscava destacar que, embora o português seja a língua oficial, como também nas outras nações africanas, o crioulo é ali a língua de comunicação diária.

A partir de 1996, quando iniciei a docência no curso de pós da Área de Estudos Comparados de Literaturas de Língua Portuguesa, procurei trabalhar também com textos de escritores cabo-verdianos, poetas e prosadores, enfatizando a língua literária do Arquipélago. Tais textos inserem-se numa das minhas linhas de pesquisa: Relações literárias entre Brasil, Portugal e África.

R.V.A. - Antes mesmo de pensarmos somente na literatura cabo-verdiana, é preciso conhecer o país. Cabo Verde permanece desconhecido para muitos, apesar da suposta proximidade com o Brasil, entre outros fatores, em virtude da língua. Poderia nos falar um pouco sobre esse país?

Situado a 455 quilômetros da costa ocidental da África, entre os paralelos $17^{\circ} 12^{\prime}$ e $14^{\circ} 48^{\prime}$ de latitude Norte, o arquipélago de Cabo Verde é formado por dez ilhas com superfície total de 4.033 quilômetros quadrados, com dois grandes grupos de ilhas, Barlavento e Sotavento, assim distribuídos:

a) o de Barlavento, ao Norte, com seis ilhas alinhadas de Noroeste a Sudeste: Santo Antão, São Vicente, Santa Luzia (quase desabitada), São Nicolau, Sal e Boa Vista; e os ilhéus quase desabitados: Pássaros, Branco e Raso; Santo Antão é a ilha mais vasta, com $875 \mathrm{~km}^{2}$ e a mais favorecida pelas chuvas; São Vicente é onde se encontra o principal porto atual (Porto Grande); São Nicolau, muito cultivada; e isoladas, ao extremo Sudeste, muito áridas, Sal e Boa Vista;

b) o de Sotavento, ao Sul, com quatro ilhas alinhadas de Sudoeste a Nordeste: Santiago, Maio, Fogo e Brava; e os ilhéus desabitados: Santa Maria, Luís Carneiro, Sapado (chamado também de ilhéu de Cima) e Grande; Santiago, a mais vasta do grupo, com $991 \mathrm{~km}^{2}$, é onde se encontra a capital, cidade de Praia; a ilha de Maio, tão árida como as do Sal e Boa Vista; a do Fogo, onde existe um 
enorme vulcão, muito ativo, tem o ponto culminante do Arquipélago, o Pico de $3.220 \mathrm{~m}$; e a ilha de Brava, onde os terremotos são freqüentes ${ }^{1}$.

Muitas ilhas são montanhosas, com clima semidesértico caracterizado pelas secas constantes que, em maior ou menor grau, atingem todas as ilhas. Ventos alísios (sopram de Leste para Oeste), principalmente o harmatão, muito quente e seco, carregado de poeira, que sopra do Saara, também conhecido por "lestada", condicionam as chuvas raras e irregulares. As ilhas de Sotavento estão mais próximas da costa africana e são mais áridas do que as de Barlavento, em sua generalidade.

Descoberto por Portugal no século XV, Cabo Verde é um arquipélago de origem vulcânica. Foi colonizado (as ilhas eram desabitadas) por meio do sistema de Capitanias Hereditárias, para onde foram levados escravos da costa da África para plantar algodão, árvores frutíferas e cana-de-açúcar.

Tornou-se independente em 5 de julho de 1975, e hoje é uma república democrática parlamentarista, cujo governo se baseia na Constituição de 1980. As eleições são presidenciais, em que se elege o Presidente da República, e legislativas, com eleição de deputados nacionais, todos para mandatos de cinco anos. O presidente do partido com maioria na Assembléia Nacional (Parlamento) é empossado como Primeiro-Ministro.

Segundo o censo de julho de 2006, a população do Arquipélago é de 420.979 habitantes. Sua moeda é o escudo cabo-verdiano.

O português é sua língua oficial, usada nas escolas, na administração pública, na imprensa e nas publicações. O crioulo cabo-verdiano é a língua do povo, oficialmente em processo de normalização, discutindo-se atualmente sua adoção como língua oficial ao lado do português.

Pouca vegetação cresce nas ilhas que têm um solo de montanhas escarpadas coberto de cinzas vulcânicas. Seu clima é quente e seco com médias anuais de $20^{\circ} / 25^{\circ} \mathrm{C}$, sofrendo as tempestades de areia oriundas do Saara, em janeiro e fevereiro.

Cabo Verde é membro da Comunidade dos Países de Língua Portuguesa (CPLP). O país é sede do Instituto Internacional de Língua Portuguesa, organismo da mesma CPLP.

1 História da Guiné e das Ilhas de Cabo Verde. Porto, PAICG/Afrontamento, 1974, p. 40. 
R.V.A. - Em que momento surgiu o seu interesse por Cabo Verde e sua literatura?

Em 1979 assistimos às aulas da disciplina Literaturas Africanas de Expressão Portuguesa, do curso de pós-graduação, disciplina que abria uma nova área de estudos na Universidade de São Paulo, a primeira universidade brasileira a introduzi-la. A Professora Maria Aparecida Santilli foi quem iniciou essa área. O curso abrangia as literaturas dos cinco países africanos de língua portuguesa: Angola, Guiné-Bissau, Cabo Verde, Moçambique e as ilhas de São Tomé e Príncipe.

Participando de seminários sobre poetas e prosadores de Cabo Verde, passei a interessar-me por sua literatura, haja vista a proximidade com a nossa literatura regionalista da década de 30. Poetas como Eugênio Tavares, Jorge Barbosa, Osvaldo Alcântara, Ovídio Martins e prosadores como Baltasar Lopes, Manuel Lopes, Teixeira de Sousa, Luís Romano, Orlanda Amarílis e Manuel Ferreira foram estudados em seminários durante o curso. Como a obra deste último escritor me interessou bastante, decidi elaborar meu projeto de dissertação de mestrado sobre o seu romance Hora di Bai.

Português de nascimento, Manuel Ferreira (1917-1997) foi para Cabo Verde como expedicionário e ali permaneceu por seis anos, de 1941 a 1947. Conviveu com o grupo da revista Claridade e exerceu decisiva influência no surgimento do grupo da revista Certeza (1943).

Em 1948 publicou seu primeiro livro com temática cabo-verdiana: Morna, coletânea de nove contos, em que o contrabando, a prostituição, o dilema entre ir e ficar são alguns motivos do universo das ilhas. Em 1958 publica Morabeza, seis contos, reunidos em 1972 aos de Morna, sob o nome de Terra Trazida. Explica o autor na apresentação desta última edição que usa e abusa, obsessivamente, de quatro elementos: "a morna, a busca de comida, o círculo do mar, o terra-longismo", pois tais temas são "quatro pólos de referência da gesta cabo-verdiana". Enfim, são imagens que constituem para Manuel Ferreira a "terra trazida" da sua estada em Cabo Verde.

Em 1962, Manuel Ferreira publica o romance Hora di Bai e, em 1971, outro romance Voz de Prisão, ambos com temas também voltados para o Arquipélago.

R.V.A. - À época os estudos sobre as literaturas africanas de língua portuguesa eram novidade no país. Como conseguiu encontrar subsídios para pesquisa num território de pesquisa ainda não explorado? 
Foi bastante difícil, pois não houve subsídios monetários, particularmente. Mas a Profa. Santilli, quando nos deu o curso, ofereceu-nos vasto material, isto é, obras literárias e teóricas que havia trazido de Portugal, onde esteve para efetuar sua pesquisa. No segundo semestre de 79, ela me convidou para participar de um Seminário sobre as Literaturas Africanas de Expressão Portuguesa, em Belo Horizonte. Foi quando conheci Manuel Ferreira, professor da disciplina na Universidade de Lisboa. ${ }^{2}$ Como ele veio a São Paulo para fazer palestras na USP, tive oportunidade de discutir o andamento da dissertação de mestrado. A partir daí passamos a nos comunicar por cartas, que me foram bastante esclarecedoras sob vários aspectos. Assim, com sua ajuda, pude elaborar um glossário de termos crioulos contidos em Hora di Bai, como anexo de minha dissertação.

Muitas dúvidas sobre a literatura de Cabo Verde também foram elucidadas pelo escritor Luís Romano, cônsul honorário de Cabo Verde no Rio de Janeiro, com quem passei também a me corresponder.

Foi de grande valia o acompanhamento seguro da Profa. Santilli durante toda fase de pesquisa, bem como na elaboração da dissertação.

R.V.A. - Qual foi o seu primeiro grande trabalho sobre Cabo Verde? Pode nos falar um pouco sobre o tema e suas escolhas de abordagem?

O romance Hora di Bai acabou por constituir minha dissertação de mestrado, apresentada em dezembro de 1980. ${ }^{3}$ Fizeram parte da banca, além da orientadora, Professora Maria Aparecida Santilli, os Professores Isaac Nicolau Salum e Benjamin Abdala Jr.

O objeto de minha explanação foi o dilema cabo-verdiano entre partir/ficar. Fruto do encontro de duas culturas que se absorveram, o homem de Cabo Verde tem vivido "consigo e para si”, feliz expressão de Orlando Albuquerque, em suas considerações sobre "Crioulismo e Mulatismo". Sua cultura, revelada nas coisas mais miúdas, no convívio, na sensibilidade, no modo de agir e de pensar,

2 Encontro de Professores Universitários de Literatura Portuguesa - UFMG/Belo Horizonte - Seminário sobre Literaturas Africanas de Expressão Portuguesa - agosto de 1979.

3 Dissertação de Mestrado: Hora di Bai - romance de Cabo Verde.

4 Cadernos Capricórnio. Lobito (Angola), 1975, p. 15. 
culmina, no romance Hora di Bai, na situação dilemática de impasse do caboverdiano: preso às raízes africanas, as emoções gritam-lhe alto e descamba para um "fatalismo romântico", gerando-lhe a necessidade de cantar a "morna", num "desabafo ou súplica plangente", como diria Luís Romano, agarrando-se a sua terra, por encontrar ali a sua razão de ser; por outro lado, a herança viageira do povo português e sua afabilidade, que lhe permitem confraternizar-se com sua gente ou outros povos, levam-no a desaguar na "morabeza", autêntico contraponto de sua solidão. De tal situação dilemática é que se apresenta em Hora di Bai o cabo-verdiano, cuja alma revela ansiedade profunda, ou seja, "qualquer coisa de indeciso entre o clima tropical e o espelho de Portugal".

António Carreira, em seu livro Cabo Verde (aspectos sociais. Secas e fomes do século $X X)^{6}$, oferece-nos informações sobre as tragédias da seca e da fome que persistem nas Ilhas desde que foram descobertas. Sobre a seca de 1941-43, da qual Manuel Ferreira recolheu os acontecimentos que compuseram a história de seu romance, Carreira informa que houve uma mortalidade pela fome de mais de 24 mil pessoas. Tal crise levou algumas personagens de Hora di Bai a migrarem para a "terra-longe", enquanto outras se tornaram paradigmas de resistência, reunindo-se em torno de líderes amotinados. Assim, um dos episódios mais dramático do romance foi o da insurreição, representado pelas "bandeiras negras", conduzindo o leitor a refletir sobre a situação de Cabo Verde em suas verdades mais cruas. Está registrado no capítulo 48 de Hora di Bai, o mais extenso de todos. Enquanto alguns cabo-verdianos já tinham partido, fugindo nos porões dos navios ou emigrados para São Tomé, outros ficaram, desfraldando "bandeiras negras", "bandeiras de fome", a insurgir-se contra os fartos celeiros de Sebastião Cunha, comerciante em São Vicente. O capitão Ambrósio comandou a turba que, "numa fúria desordenada", agita bandeiras pretas aos gritos de "Ca-chu-pa! Mi-lho!" e de "Fòòò-me! Fòòòme!" O poema "Capitão Ambrósio"”, de Gabriel Mariano, poeta da ilha de São Nicolau, servirá de intertexto para este capítulo.

5 Todos os termos crioulos que uso nestes "Caminhos..." serão explicados mais adiante, extraídos do Glossário de minha dissertação.

6 Lisboa, Ulmeio, 1984, p. 17-19.

7 Confira-se em FERREIRA, Manuel. No Reino de Caliban I. Lisboa, Plátano, 1975, p. 176-79. 
O tema da "partida", que dá nome ao romance, apresenta-se nos sentidos de "emigração" e "evasão". Emigração para a ilha de São Tomé, com provável imperativo de sobrevivência, não obstante os prognósticos de trabalho sejam em condições sub-humanas, pois "Terra-longe tem gente-gentio, gente-gentio come gente", estribilho do poema "Terra-longe", de Pedro Corsino Azevedo, poeta também da ilha de São Nicolau. A emigração para São Tomé, tratada no capítulo 46, tem este poema como intertexto.

A evasão manifesta-se como desejo coletivo, ligado a uma atitude cultural, pois, segundo o narrador de Hora di Bai,

De novo se abria em São Vicente um vazio intelectual, acendido e reacendido por um ou outro nome de Claridade. Até que novo grupo se formasse e se impusesse. ${ }^{8}$

O narrador refere-se aqui aos intelectuais da revista Claridade (1936) e aos da revista Certeza (1944). Como desejo individual, porém, destaca-se Nha Venância, personagem feminina, cujo desejo de partir identifica-se com o do homem cabo-verdiano, para quem a vida é um destino do qual não pode fugir. Símbolo da "Tellus Mater", na sua infinita capacidade para amar e compreender, Venância emerge daquele mundo como paradigma da resistência, preservando, entretanto, o coração pleno de "morabeza", verdadeiro contraponto de seu povo. Como disse o poeta Jacinto Moreno:

Nha Venância, veja. Cabo-verdiano deve agarrar-se à sua terra. Encontrar aqui, nas horas de infortúnio, a sua razão de ser. Então, vamos todos desertar??

As palavras do poeta servirão de código a solicitar os conteúdos distantes e esquecidos de sua infância, perfazendo o círculo de associações em que se soluciona, inesperadamente, o dilema no qual está envolvida. Ali, na sua terra "nhanhida", "onde as coisas se sucedem na quietação do perfeito entendimento", soubera encontrar o seu caminho.

8 Hora di Bai. Lisboa, Plátano, 1972, p. 163-64. Todas as citações que farei de Hora di Bai serão desta edição.

9.Ibid., p. 258. 
Nha Venância acompanhou à porta o poeta Jacinto Moreno. Depois recolheu à sala e deixou-se ficar, longo tempo, na cadeira de balanço. Balançando, cismando. [...]

Bia, lá dentro (teria a cachupinha pronta?) despreocupadamente trauteava a morna de antigamente. E Joana, que não dava sinal de si, onde estaria? Chamou por ambas.

"Bia! Joana!"

Apareceram as duas e nha Venância, erguendo-se da cadeira de balanço e mirando-se no espelho, disse-lhe que a partida para Lisboa ficava adiada. ${ }^{10}$

Assim, cada um seria livre para escolher entre "partir ou ficar", inseparáveis na coexistência dinâmica que constitui a vida de cada cabo-verdiano, sempre oscilante na sua "hora di bai".

Finalizando, diria que o romance Hora di Bai não indica a prevalência do partir sobre o ficar, nem deste sobre aquele, mas significa partir e ficar interseccionados como dois pólos que se desdobram num processo dialético de interpenetração contínua, resultado das duas culturas que redundaram no homem cabo-verdiano. Viver em Cabo Verde é querer ficar e ter de partir e também querer partir e ter de ficar, em que qualquer decisão será sempre provisória.

Os versos do batuque santiaguense postos no frontispício do romance Chiquinho de Baltasar Lopes podem definir, liricamente, o que Hora di Bai, em síntese, acaba por significar:

Corpo, qu'ê nego, sa ta bai; (O corpo, que é escravo, vai);

Coraçom, qu'ê fôrro, sa ta fica... (O coração, que é livre, fica...)

Ao final da dissertação incluí um glossário sobre expressões crioulas, uma vez que a obra de Manuel Ferreira registra também a língua-mãe de Cabo Verde, buscando reproduzir os matizes do linguajar afetivo.

10 Hora di Bai, p. 263-264. 
R.V.A. - Este glossário foi publicado depois ou permaneceu parte da dissertação? Poderia dar alguns exemplos de palavras e expressões em crioulo que foram incluídas nesse levantamento?

Permaneceu como Anexo da dissertação. A título de exemplos, seguem-se algumas palavras e expressões extraídas do Glossário:

Bai-partida, despedida, corresponde a "vai".

Câ tem nada na ês bidal más grande que amor - não há nada nesta vida maior que o amor. Estes versos iniciam a morna "Força de crecheu", de Eugênio Tavares.

Cachupa-alimentação de cunho local, feita à base de milho. Para Luís Romano, o termo "catchupa" ou "cachupa" teria sido derivado, talvez, do ambundo "cachupa": palha de milho para cigarro. Segundo ele, existem três principais versões:1. cachupa-água-e-sal, que é baseada no milho cochido, ou semi-esmagado no pilão, esfarelado no balaio de tenter reposto a cozinhar só com água e sal; é a alimentação dos coitadinhos; 2. cachupa-dos-remediados, à qual se adiciona um pouco de feijão seco, agriões, um naco de toucinho ou posta de atum e ainda algumas batatas doces ou rachas de mandioca, inhame, banana verde ou abóbora; 3. cachupa-de-gente-branca, que pode servir para uma receita especial e tem a seguinte preparação: milho cochido e esfarelado, à mistura com feijão, fava ou ervilha, numa caldeira com água, onde se juntam temperos verdes, hortaliças, toucinho ou lingüiça, adubado ainda com rodelas de paio, cebola, alho, folha de louro, mandioca nova ou batata inglesa; na falta de toucinho usa-se banha de porco que lhe dá sabor especial ${ }^{11}$.

Chuchinha-amorzinho.

Codê - filho caçula.

Còladeira - dança e música típica de Cabo Verde; de ritmo excitante, "o colâSanjon (de São João) é uma dança popular animada por grandes tambores, percutidos num dado ritmo, e na qual pares sucessivos de homens e mulheres vão tocando sensualmente a parte anterior do corpo"12.

Crê ou qrề- querer amar, desejar.

Crecheu ou cretcheu - de crê + cheu - querer muito.

Fedagoza - planta cujas sementes torradas semelham grãos de café.

11 "Renascença de uma civilização no Atlântico Médio". Em Ocidente. Lisboa, 73 (355): 212-26, 1967, p. 212. 12 DUARTE, Manuel. "Caboverdianidade e africanidade”. Em Vértice. Coimbra, 14: 639-44, 1939, p. 640. 
Fije - filho (a).

Hora di bai - hora da partida, hora da despedida.

Lestada - vento ardente, abafadiço, vindo do Saara, também chamado de harmatão ou suão pelo cabo-verdiano.

Móia - contrabando; farinha, mercearias, etc. salvados dos barcos encalhados.

Morabeza - o mesmo que amorabilidade - modo afetivo de ser, misto de gentileza e liberalidade; ânsia de convívio e de trato humano como resposta ao isolamento geográfico, afabilidade como compensação da aridez do ambiente. A "morabeza" seria o contraponto da solidão do cabo-verdiano.

Morna - poesia, música e dança típica de Cabo Verde. Para Manuel Ferreira, o cabo-verdiano encontra na morna "o expoente máximo da sua sensibilidade. Através dela o crioulo exprime a saudade do que deixou, do que não viveu, do que desejaria ter vivido e ainda de tudo o mais quanto nos estratos profundos do seu subconsciente se agita e desencadeia em torrente lírica"13.

Nhanhida - adjetivo relativo à terra - infeliz, desgraçada, amaldiçoada.

Sabe - saboroso que sabe bem, agradável; para Baltasar Lopes assenta-se, talvez, no verbo saber, no sentido de ter sabor, provindo da expressão isto sabe bem, de que se teria isolado a forma verbal, portadora da idéia básica ${ }^{14}$.

Sabura - gostosura.

Tonguinha - dança cabo-verdiana que desapareceu; parecida com a coladeira atual.

Tracolança-doidivanas, menina da vida, que é de todos.

Vovô- prisão.

R.V.A. - Qual seria, a seu ver, o propósito no uso do bilingüismo portuguêscrioulo na literatura cabo-verdiana?

Em 1985, no Colloque International Les Litteratures Africaines de Langue Portugaise, em Paris, apresentei a comunicação "Hora di Bai: típica síntese cabo-verdiana"15.

13 Aventura Crioula. 2 ed. Lisboa, Plátano., 1973, p. 166.

14 Op. cit., p. 148.

15 Colloque International Les Litteratures Africaines de Langue Portugaise, promovido pela Fundação

Calouste Gulbenkian, em Paris. 
Na introdução focalizei o aspecto do bilingüismo do cabo-verdiano que se expressa em crioulo, sua língua de berço, identificado com o falar quotidiano, e em português que desempenha papel importante em nível das classes mais letradas. A literatura também se apresenta em dupla vertente: a das obras em crioulo, veículo do lirismo popular, principalmente pelas mornas dedicadas às ilhas do Arquipélago e a seu povo; e a das obras em língua portuguesa.

Para Manuel Ferreira (Aventura Crioula) o dialeto crioulo foi-se legitimando em nível de escrita desde o século XVII, quando já se encontram documentos em crioulo; em fins do século XIX, o Almanaque Luso-Africano (o $1^{\circ}$ volume é de 1894 e o $2^{\circ}$ é de 1899) reproduz historietas, anedotas, lendas, poesias, mornas, letras de música, algumas em crioulo; no começo do século XX, Eugênio Tavares e Pedro Cardoso valorizam o crioulo como organismo vivo e funcional em publicações de revistas e jornais ${ }^{16}$.

Posteriormente a revista Claridade, em seus primeiros números (1936), registra alguns textos em crioulo. Baltasar Lopes coloca-se "na vanguarda do movimento de nobilitação do dialeto crioulo de Cabo Verde e ajudou a dar-lhe o prestígio que, embora penosamente, vai conseguindo ${ }^{17}$.

R.V.A. - Um romance importante como Hora di Bai - obra inaugural de uma literatura em consolidação - tem que características em termos de estrutura narrativa?

Apresentei, em 1986, no II Congresso Brasileiro de Estudos Afro-Asiáticos (ALAAB), uma comunicação com o título "A voz do narrador em Hora di Bai"

Procurei, de início, enfatizar, como tema do romance, a realidade histórica e geográfica, a seca de 1943, num discurso interessado e dirigido de modo a solicitar do leitor múltiplas interrogações sobre aquele universo de estiagem e de fome.

No capítulo 1 do romance, o narrador comporta-se principalmente como mero informante, sugerindo a presença de um autor-implícito, com objetivo de situar a grande seca no tempo (1943) e no espaço (ilha de São Nicolau).

16 Op. cit., p. $110-111$.

17 Id. ibid., p. 112.

18 II Congresso Brasileiro de Estudos Afro-Asiáticos (ALAAB) - USP. 
A partir do capítulo 2, sua imagem torna-se a de um narrador convencional, onisciente, elegendo e nomeando personagens, individualizando aquela gente que se comprime no veleiro: visão "por detrás", como se conhecesse tudo acerca de acontecimentos e de personagens nos seus mais íntimos detalhes.

A narrativa faz-se na $3^{a}$ pessoa, mas nem sempre se apresenta como voz individual do narrador, em que outras vozes são absorvidas, projetando idéias e sentimentos coletivos. Nota-se, por vezes, a instauração de uma sintaxe interrogativa que estrutura o discurso do narrador em relação às carências mais essenciais para a subsistência em São Nicolau: bananas, papaias, batatas-doces, feijão, mandioca e milho. Tais indagações orientam-se mais para questionar aqueles que manipulam os poderes.

O recurso ao ponto de vista dramático conduz o leitor a visualizar cenas sem intermediação do narrador, objetividade que permite caracterizar melhor as personagens, reproduzindo-lhes os matizes da linguagem afetiva em suas peculiaridades de expressão. São momentos importantes, pois é também possível documentar o crioulo como organismo vivo de uso diário do cabo-verdiano. Confira-se este exemplo:

[Conchinha] Olhou atordoada para todos os lados. E enquanto os seus olhos se afaziam à luz mortiça dos candeeiros, descortinou grupos de pessoas amontoadas na ponta-da-praia, deitadas, abandonadas à noite.

Eh bocê, dzê'me um cosa. Q'zê quil? ${ }^{19}$ (Eh você, diga-me uma coisa, o que é aquilo?)

Em alguns momentos, cria-se uma situação dialógica entre narrador e narratário (destinatário intratextual do discurso narrativo), por meio de alusões diretas, exclamações, indagações, marcas lingüísticas que concorrem para a persuasão da matéria diegética, a fim de se completar a missão da mensagem:

Nossa terra estava mesmo a acabar em nada. Estava, sim senhor. Senhor, não havia ninguém capaz de lhe deitar a mão? ${ }^{20}$

19 Hora di Bai, p. 86.

20 Ibid., p. 171. 
Em certo ponto do percurso narrativo, com o predomínio da função conativa, o narrador ultrapassa o narratário imediato, atingindo o contexto social e cultural em que se insere o romance. Assim, no capítulo 41, o narrador expõe, no primeiro parágrafo, o encontro entre nha Venância e Dr. França. A seguir, intercala-se um diálogo entre o narrador e Dr. França, formando-se uma base comum, um tecido único, como se fosse um ser duplo, com perfeita reciprocidade, em que ambos passam a coexistir no mesmo mundo. A mensagem, se fosse transmitida por nha Venância ao Dr. França, perderia sua eficácia, pela carência psicológica entre os dois. O "espaço de vida" 21 de ambos não manteria identidade, sendo impossível uma interação dinâmica entre eles pela linguagem. A intromissão do narrador, situando-se em nível actancial, confere-lhe participação ativa, tendo sido decisiva para o destinatário apreender a mensagem:

Dr. França, espera. Não tenhas pressa. Escuta esta mulher. Ouve-a que ela traz a alma pura e o coração a sangrar. Olha-a nos olhos, Dr. França. Olha-a bem. [...] Escuta-a, Dr. França. Ela vem-te falar da seca, da fome. Vem-te falar da leva para São Tomé.[...] Escuta-a, escuta-a, Dr. França, que a sua voz é a voz da consciência torturada. A voz da razão a sangrar. Ouve-a, ouve-a, Dr. França. Vês, como te faz bem² ${ }^{22}$.

Através dos sentidos, visão e audição, é estabelecida uma união inteiramente nova, mais forte, entre narrador e destinatário. A adesão do narrador a Venância, em seus aspectos afetivos e ideológicos, consuma-se inteiramente de tal forma que, ao assumir uma posição ativa, o porta-voz da narração persuade o Dr. França em favor da coletividade.

Procurei também demonstrar que a dualidade da linguagem pelo narrador busca exprimir os dois mundos em que a obra se insere, o português e o crioulo, visando selar um encontro de 500 anos. O crioulo, identificado com a voz da emoção, acaba por resultar em prestígio de expressão cultural que vem adquirindo desde os primeiros números de Claridade (1936).

21 Segundo Fritz Heider, "espaço de vida" ou "ambiente subjetivo" consiste nos diferentes tipos de relações mantidas com pessoas, objetos e acontecimentos. Em sua Psicologia das Relações Interpessoais. Trad. de Dante Moreira Leite. São Paulo, Pioneira, 1970, p. 28.

22 Hora di Bai, p. 206. 
R.V.A. - Voltando à questão do bilingüismo, que sempre traz muitas dúvidas e questionamentos. Poderia falar-nos mais a respeito?

Pronunciei uma palestra sobre o crioulo e a língua portuguesa, em abril de 1988, na FUNDAP (Fundação do Desenvolvimento Administrativo) em São Paulo. A Fundação dedica-se à consultoria organizacional, formação de recursos humanos, desenvolvimento de novas tecnologias de gestão administrativa e pesquisa aplicada para a administração pública do Estado de São Paulo, e trabalhos em outros estados e municípios brasileiros, respondendo também a demandas do governo federal e desenvolvendo projetos internacionais. Naquela altura, a FUNDAP estava prestando serviços ao Governo de Cabo Verde, contando com estudantes-estagiários do Arquipélago.

Procurei demonstrar, durante a palestra, como convivem no Arquipélago o crioulo e a língua portuguesa, expressão do falar quotidiano e expressão oficial e das classes mais letradas, respectivamente. Procurei enfatizar também as duas vertentes na literatura, mencionando alguns fragmentos de textos de poetas e trovadores.

A palestra foi bastante dinâmica, pois houve colaboração dos estudantes caboverdianos ali presentes. Contaram que, nas escolas, embora se utilize a língua portuguesa durante as aulas, nos intervalos e recreios seja comum os estudantes comunicarem-se em crioulo, inclusive quando conversam com os professores.

Cesária Évora, conhecida como "a diva dos pés descalços”, por se apresentar assim nos palcos, por solidariedade aos sem-teto, às mulheres e às crianças pobres de seu país, foi bastante lembrada pelas mornas que canta e encanta.

R.V.A. - Percebemos em seus textos, falas de congresso e aulas a freqüência com que são citados periódicos como Claridade. Qual a importância dos periódicos na literatura cabo-verdiana?

Para comemorar os 50 anos da publicação da revista Claridade (1936/1986), publiquei no jornal O Estado de S. Paulo o artigo "Um símbolo do Verde Arquipélago da África"23.

23 "Um símbolo do Verde Arquipélago da África". O Estado de S. Paulo. Suplemento Cultural. São Paulo, 9/8/86, n. 320, p. 9 . 
Já em 1935, o poeta Jorge Barbosa, antecipando-se ao grupo claridoso, publicara a coletânea Arquipélago, com preocupações para o chão crioulo. Aquelas "Ilhas perdidas/ no meio do mar,/ esquecidas/ num canto do mundo/ que as ondas embalam,/ maltratam,/ abraçam.../" revelavam o clamor do poeta para o problema de Cabo Verde.

Os escritores brasileiros da década de 30, principalmente aqueles cujas obras tinham propostas renovadoras, deram sua contribuição para que se deflagrasse o movimento claridoso em Cabo Verde. José Osório de Oliveira, no n 2 de Claridade, publicado em agosto de 1936, assim sintetiza a afinidade dos caboverdianos com nossos escritores:

Os cabo-verdianos precisavam dum exemplo que a literatura de Portugal não lhes podia dar, mas que o Brasil lhes forneceu. As afinidades existentes entre Cabo Verde e os Estados do Nordeste do Brasil predispunham os cabo-verdianos para compreender, sentir e amar a nova literatura brasileira. Encontrando exemplos a seguir na poesia e nos romances modernos do Brasil, sentindo-se apoiados, na análise do seu caso, pelos novos ensaístas brasileiros, os cabo-verdianos descobriram o seu caminho.

A revista portuguesa Presença também teve sua contribuição. Desde 1927, os jovens poetas cabo-verdianos puderam ter contato com os novos poetas portugueses e com os novos aspectos de sua poesia. Assim é que, em 1937, quando se publica o n. 3 de Claridade, a revista Presença registra o fato como "primeira manifestação de autêntico espírito moderno português fora da Metrópole". Destaca também poemas de Jorge Barbosa, Manuel Lopes e Osvaldo Alcântara, bem como um fragmento do romance de Baltasar Lopes, que se "afigura mais do que uma esperança de romancista". Será o romance Chiquinho, que só será publicado em 1947, mas já pronto em 1940, segundo Manuel Ferreira.

Publicada em Mindelo, ilha de São Vicente, Claridade alcançou nove números, ao longo de duas fases, que vão de 1936 a 1960: a 1ª essencialmente literária, com três números (dois em 36 e um em 37); a $2^{\mathrm{a}}$ com seis números (de 47 a 60). O grupo responsável pela $1^{a}$ fase, Baltasar Lopes, Jorge Barbosa e Manuel Lopes, preocupado com o processo de formação social das ilhas e com suas raízes, pôs em primeiro plano a redescoberta da evolução social crioula, realida- 
de até então ignorada de certa forma. Naquele primeiro momento, impunha-se ao grupo, pensar o problema do Arquipélago em sua dimensão insular.

R.V.A. - Então podemos dizer que o periódico foi um importante meio de expressão dos intelectuais e escritores cabo-verdianos?

Sim, não só os intelectuais da $1^{\mathrm{a}}$ fase, como já foi mencionado, como também os da $2^{\mathrm{a}}$ fase de Claridade, passando a incorporar valores de outras gerações, com novos escritores, alguns do grupo da revista Certeza e outros do Suplemento Cultural. Aqueles foram impulsionados pelo movimento neo-realista de Portugal, iniciado em 1940; estes foram estimulados pelo amor aos estudos da terra e, principalmente, pela preocupação em inseri-la no contexto universal. Era, ainda, a inquietação da $1^{a}$ fase de Claridade, com suas preocupações diante dos problemas circundantes, na busca e reforço da identidade do próprio povo. Era preciso, de vez por todas, que Claridade fincasse os pés na terra, ainda que seca e estéril, ainda que terra "nhanhida".

Procurei enfatizar que, ao longo dos 50 anos, muitas obras de poesia e de ficção foram publicadas em Cabo Verde. A maioria reitera o drama das ilhas em sintonia com a revista Claridade, entendida por Manuel Ferreira como autêntico "símbolo" do Verde Arquipélago da África.

R.V.A. - Existe uma resenha sua, sobre a obra Literaturas Africanas de Expressão Portuguesa, de Manuel Ferreira. Poderia nos falar sobre este seu trabalho? Manuel Ferreira chegou a ler a resenha?

Publiquei na revista Afinal, n 162, de 6 de outubro de 1987, uma resenha de Literaturas Africanas de Expressão Portuguesa, de Manuel Ferreira, obra históricoliterária, editada em São Paulo, pela Ática, em 1987. Tal publicação brasileira acrescenta e enriquece a edição portuguesa de 1977.

$\mathrm{Na}$ Introdução, o autor assim justifica o título de mais este trabalho de historiador e ensaísta literário: "Literaturas que, sendo africanas, tendo um conteúdo africano, são expressas, são 'ditas' em língua portuguesa, o que por si só afasta toda e qualquer idéia de reserva mental e colonial ou colonialista”. A seguir, Manuel Ferreira trata objetivamente da questão da existência das literaturas na África portuguesa, assinalando suas duas vertentes: a colonial, centrada no homem europeu, em que o africano constitui mero acidente; e a africana, em 
que o negro passa a ser "privilegiado e revestido de um solidário tratamento literário", preenchendo os apelos da enunciação e, quase sempre, sujeito do enunciado, enquanto personagem. Se, por um lado, os textos coloniais prolongam a realidade colonial, os textos africanos, negando a legitimidade do colonialismo, revelam e valorizam o universo da África.

Os fundamentos das literaturas africanas, em cada um dos cinco países que têm a língua portuguesa como instrumento de unidade e de comunicação internacional, resumem-se, segundo o autor, a partir de determinadas obras:

- em Cabo Verde, com a revista Claridade (1936-1962), essencialmente literária em sua primeira fase, a partir da qual os escritores assumem uma nítida consciência regional;

- em São Tomé e Príncipe, após os poemas de Franciso José Tenreiro, identificados com a voz coletiva do homem-negro, reunidos em Ilha do Nome Santo (1943);

- em Angola, com a revista Mensagem (1951-1952), conseqüência do projeto cultural e político do Movimento dos Novos Intelectuais de Angola;

- em Moçambique, a partir da revista Msabo (1952), primeira tentativa de um projeto coletivo nacional;

- e em Guiné-Bissau, após a antologia poética posterior à independência, Mantenhas para quem luta (1977), que reúne catorze jovens poetas.

Literaturas africanas de expressão portuguesa, fruto de investigação de Manuel Ferreira sobre a África portuguesa, garante uma visão abrangente e segura a todos quantos se dedicam ao estudo das letras africanas em língua portuguesa.

Sim, Manuel Ferreira leu esta resenha, como leu outros textos publicados, inclusive minha dissertação de mestrado sobre Hora di Bai. Lia, sempre com muito interesse, e opinava. Julgava interessante minha abordagem como brasileira.

Mantivemos nossa amizade, principalmente, devido ao interesse, dele e meu, pelas literaturas africanas de língua portuguesa. Nossos encontros eram em São Paulo, especialmente na USP durante os Seminários e outros eventos dos quais participávamos. Havia sempre o que aprender com ele. Além das obras de ficção, publicou vários ensaios, como: $O$ discurso no percurso africano; 50 poetas africanos e outros já mencionados por nós.

Em Portugal, foram poucos nossos contatos, pois eu costumava ir em agosto e setembro, quando o professor estava em férias fora de Lisboa. Em novembro de 96, estando em Lisboa, recebi um telefonema dele de Setúbal, 
onde estava fazendo exames cardiológicos. Disse-me que, quando eu voltasse no ano seguinte para continuar a pesquisar sobre Cabo Verde, sua biblioteca particular em Linda-a-Velha estaria à minha disposição. Não houve tempo. Em março de 1997 Manuel Ferreira faleceu.

Três ou quatro anos depois estive com Orlanda Amarílis, sua mulher, que me contou, muito comovida, ter feito uma exposição de e sobre Manuel Ferreira em Leiria, sua cidade natal. Lá estavam minha dissertação de mestrado e algumas publicações minhas de jornais e revistas.

R.V.A. - Gostaríamos que falasse um pouco a respeito das origens do crioulo e da literatura cabo-verdiana?

Em abril de 1995 participei do I Simpósio de Língua Portuguesa em África e Ásia, promovido pelo Liceu Literário do Rio de Janeiro, coordenado pelo saudoso prof. Sílvio Elia. Apresentei a comunicação: "Crioulo e português: vertentes lingüísticas da literatura de Cabo Verde”, publicada posteriormente em Confluência n 12. Rio de Janeiro, Liceu Literário, 1996, p. 137-146.

Abordei de início o povoamento difícil das ilhas que se deu com os colonizadores portugueses e, em maior número, com uma população escrava de origem africana, particularmente da Guiné, que foi trabalhar nas plantações de tabaco, café e cana de açúcar. Para que houvesse intercâmbio de comunicação lingüística, surgiu o falar de emergência, o "pidgin" que, contrariamente ao que aconteceu no Brasil, onde o processo colonizador, por razões várias, foi profundo e duradouro, lá se estabilizou, acabando por converter-se em crioulo.

O crioulo de Cabo Verde, como os crioulos em geral, segundo Baltasar Lopes, teria tido uma fase bilingüe inicial, seguindo-se outra em que o africano já assimilara uma estrutura gramatical simplificada do português. Partindo-se desta fase é que se pode compreender sua vitalidade, tornando-se impossível sua erradicação como fala comum e até sua viabilidade literária ${ }^{24}$.

Como o crioulo não se alastrou homogeneamente por Cabo Verde, acabou por distribuir-se em dois grandes grupos: o de Barlavento (Santo Antão, São Vicente, São Nicolau, Boa Vista e Sal) e o de Sotavento (Maio, Santiago, Fogo e Brava). Já em 1880, Adolfo Coelho distinguia duas formas do crioulo no 
Arquipélago, considerando principalmente a pronúncia de algumas palavras ou sons, e também o acento: o crioulo rachado, fundo, vejo, falado sobretudo no interior das ilhas, e o crioulo leve, levinho, falado nas regiões mais urbanizadas, por pessoas com algum conhecimento da gramática portuguesa ${ }^{25}$.

Adolfo Coelho cita algumas cartas, frases diversas e adivinhações do crioulo rachado, como documentos do dialeto de Santiago. Cito, a seguir, um fragmento da Carta $1^{\mathrm{a}}$ :

Nha amigo. - Cu préssa en scrêbê ês dôs fója di papel, qui dentro d'ês carta en tâ manda nhô.

Talvêz algun cúsa, palabra, ou móde nhú crê, stâ êrrado. Cuza qu'en câ tâ dubida; pamóde pâ más criôlo qui nós di Cabo Berde nú sabê, sénpre nu tâ ncontra dificuldade ou enbaráço, quel'ora qui nú pêga na péna pâ nu scrêbê na nós lingua.

(Meu amigo - Com pressa escrevi estas duas folhas de papel que dentro desta carta lhe envio.

Talvez alguma cousa, palavra ou como quiser, esteja errada. O que não duvido, porque por mais crioulo que nós de Cabo Verde saibamos, sempre encontramos dificuldade ou embaraço logo que pegamos na pena para escrevermos na nossa língua. $)^{26}$.

A variante de Sotavento, recomendada como língua-base pelo Colóquio de São Vicente (1979), forma um grupo dialetológico com o da Guiné portuguesa, que se explica pela presença cabo-verdiana nessa região, e pela história política e social, pois até 1879 a Guiné esteve administrativamente ligada a Cabo Verde. As maiores diferenças verificam-se entre o crioulo de Santiago (grupo de Sotavento), conhecido por badiu, e o de Santo Antão (grupo de Barlavento). É possível distinguir no crioulo de Santiago as variantes rural e urbana, sendo esta a que tem maior influência do português contemporâneo.

25 COELHO, Adolfo. Os dialectos românicos ou neo-latinnos na África, Ásia e América. Em Estudos linguiisticos crioulos. Reedição de artigos publicados no Boletim da Sociedade de Geografia de Lisboa. Introdução e notas de MORAIS-BARBOSA, Jorge. Lisboa, Academia Nacional da cultura portuguesa. 1967 , p. 5.

26 Id., ibid., p. 5. 
A seguir mencionei que, tomando o português como língua-fonte, os desvios e mutilações sofridas na fonologia, morfologia e sintaxe acabaram por resultar o falar cabo-verdiano, como se pode depreender em alguns exemplos:

a) na fonologia: "perdê" por perder; "rabatá" por arrebentar; "xávna" por chávena; b) na morfologia, houve muitas alterações: o artigo definido desaparece; os substantivos e adjetivos não possuem flexão de número; os verbos, via de regra, reduzem-se à forma do infinitivo com apócope do -r; as desinências pessoais são suprimidas, sendo indicadas pelos pronomes pessoais ("êl bê" = ele vem); as desinências modais e temporais são expressas por formas auxiliares ("êl ta kantába" = ele cantava); c) na sintaxe, há supressão de nexos gramaticais, subvertendo a sintaxe regular: "dá kabóle água" = dá água ao cavalo; como o artigo definido desaparece, em São Nicolau, curiosamente conserva o "s" na forma do plural, principalmente nos topônimos: "spedra" = as pedras; "skazina" = as casinhas.

Quanto à tradição literária, data de fins do século XIX, quando o Almanaque Luso-Africano reproduziu historietas, anedotas, lendas, poesias e letras de canções. Em 1910 José Bernardo Alfama publicou Canções crioulas e músicas populares de Cabo Verde. Mas até as primeiras décadas do século XX, o acervo literário em crioulo constitui-se praticamente de poesia lírica e satírica, na forma de mornas e finançons. Vinculadas ao cancioneiro popular, há inúmeras mornas anônimas, enquanto outras foram compostas por troveiros bastante conhecidos e prestigiados pelo povo, como Beleza (Xavier da Cruz) e Eugênio Tavares. Nhô Eugênio, como ficou conhecido, procurou expressar em suas mornas o ambiente de Brava, sua ilha natal em Mornas - cantigas crioulas, publicação póstuma em 1932. As finançons ou finaçons são cantigas típicas da ilha de Santiago, com elementos satíricos e morais.

Eugênio Tavares (1867-1930) e Pedro Cardoso (1890-1942) foram os primeiros a compor efetivamente o núcleo literário em crioulo, estimulando a formação de uma vanguarda nos anos 30. Escreveram no grupo dialetológico de Sotavento, variante utilizada por maior número de falantes, e, segundo Baltasar Lopes, mais adequado literariamente do que a variante de Barlavento, por esta ser menos harmônica.

Em 1936, o crioulo cabo-verdiano consagra-se com textos na página de rosto dos dois primeiros números de Claridade que se coloca na vanguarda do enobrecimento da língua nativa: 
"Corpo, qu'ê nego, sa ta bai;

Coraçom, qu'ê fôrro, sa ta fica...

Chiquinho será o primeiro romance moderno de Cabo Verde. Seu autor, Baltasar Lopes, publicou primeiramente dois capítulos nos números 1 e 3 de Claridade (1936 e 37) e mais tarde, em 1947, publicou o romance em Lisboa. Vale notar que, ao lado do cenário físico e social, o autor procura fixar construções da língua nativa, pelas falas das personagens e pelo discurso do narrador, acentuando a cabo-verdianidade do Arquipélago. Utilizando-se do léxico crioulo ("mantenhas" = saudações; "codê" = filho mais novo) e de formas sintáticas que representam rupturas ao modelo tradicional ("No Daisy mando vocês umas pranchas para um portal novo"), Baltasar Lopes torna-se pioneiro no espaço africano de língua portuguesa.

Outros autores têm estimulado a produção literária com textos inteiros em crioulo, buscando traduzir mais fielmente o universo sociocultural do Arquipélago. Dentre os poetas citamos: Ovídio Martins, autor de Caminhada (1962), parte em crioulo, e Kaboverdiano Dambará, autor de Noti (1964), poemas de protesto e de combate.

Na narrativa, Luís Romano publica em 1973, no Brasil, Lzimparin/Negrume, em português e em crioulo de Santo Antão, sua ilha natal, constituindo a primeira experiência do Arquipélago em livro. Mais tarde, Ilha (1991) terá algumas narrativas também na modalidade crioula de Santo Antão e outras na de Santiago. Em prosa crioula temos também a obra romanesca Oju d'Agu (1987), de Manuel Veiga.

Recomendando a variante de Sotavento como língua-base, o Colóquio sobre o Crioulo (São Vicente, abril de 1979) sugere ao escritor que "incentive o uso e prática do Crioulo como língua de produção literária” e que colabore com os lingüistas para o estudo e aprofundamento de seus valores intrínsecos, "de forma a prevenir o seu desvirtuamento e garantir a sua pureza".

Ao concluir assinalei que as obras literárias cabo-verdianas, em sua maioria, continuarão a ser escritas em português, língua que se abriu a esse novo espaço africano, modificando-se, mas conservando a sua unidade. Temos ali uma nova norma, na acepção de Coseriu, isto é, realização do sistema sob formas determinadas socialmente, norma que se vem ajustando à expressão literária, alimentando-se no coloquial do dia-a-dia. 
R.V.A. - A senhora dedicou outros trabalhos às implicações lingüísticas e literárias do crioulo de Cabo Verde?

Participei de um Colóquio na UNESP de Araraquara, em abril de 1996, com a comunicação "Língua e cultura em Cabo Verde"27.

Posteriormente, o texto foi publicado pelo livro Sobre as naus da iniciaçãoEstudos de Literatura e História. São Paulo, UNESP, 1997, p. 287-298.

Ressaltei que a língua portuguesa "cabo-verdianizada" continuará a servir de instrumento de revitalização cultural, alcançando uma ambivalência lingüística, isto é, a "diglossia”, pela interferência do crioulo, revelando-se uma língua atual.

R.V.A. - Apesar da adoção da língua portuguesa para a maioria das obras literárias, existe a possibilidade de uma futura consolidação do crioulo como "língua literária"?

Prado Coelho, considerando que o destino da língua literária está sempre ligado ás estruturas sociopolíticas e às suas alterações, solicitou a seguinte pergunta a qualificados escritores e estudiosos ${ }^{28}$ :

Portugal encontra-se no momento crítico duma das grandes viragens da sua História: cinco séculos após os Descobrimentos e a Conquista, inicia o processo da descolonização, empenhando-se em contribuir para que as antigas colônias edifiquem um futuro independente, digno e próspero. Mas a presença da cultura portuguesa permanece através da língua que lhe serve de veículo. Qual a sorte dessa língua em África, no domínio da produção literária?

Acrescentou ser enorme tarefa

27 Colóquio Literatura e História: Portugal em foco - UNESP - Araraquara, 1996.

28 Cf. "Crioulo e português: vertentes da literatura de Cabo Verde". Em Abrindo caminhos. Homenagem a Maria Aparecida Santilli. São Paulo, Coleção Via Atlântica, n 2, 2002, p. 46- 52. Este texto procurou ressaltar o que escritores e estudiosos portugueses e africanos manifestaram a respeito de "O futuro do português como língua literária em África", a propósito de solicitação feita por Jacinto do Prado Coelho, publicada em Colóquio/Letras, 21, set/74, p. 5-16. 
planear e desenvolver uma ação político-cultural para expansão e consolidação em África da língua comum, estudando e respeitando, ao mesmo tempo, como se verifica em relação ao Brasil, a personalidade e o estilo (inclusivamente lingüístico) de cada um dos novos países irmãos.

Como meu interesse era tratar da língua literária em Cabo Verde, ative-me aos seus escritores que responderam à questão. António Aurélio Gonçalves, em seu depoimento, enfatiza não ser possível substituição do português pelo crioulo, porque este não dispõe de características estéticas capazes de promover revoluções literárias que não se improvisam de um momento para outro. Citando escritores que já produziram obras valiosas, Jorge Barbosa, Teixeira de Sousa, Baltasar Lopes, Manuel Lopes, Jaime de Figueiredo, ressalta que escreveram em português, ainda que algum procurasse se aproximar do crioulo, captando a atmosfera regional. Cita também tentativas duma literatura de expressão crioula, dignas de nota, como poesias de Eugênio Tavares e de Pedro Cardoso.

Mas Aurélio Gonçalves diz que falta ao crioulo um conjunto de características estéticas que não se improvisam e ainda há o obstáculo para a difusão das letras cabo-verdianas. Tirando ilações sobre o futuro do português literário em Cabo Verde, conclui dizendo que haverá aqueles que se dedicarão ao cultivo do crioulo, mas os melhores seguirão o exemplo do Brasil, das Américas e das antigas colônias da França e da Inglaterra, não hesitando em adotar a língua de suas antigas metrópoles.

Manuel Ferreira, abordando o caso especial de aculturação e de bilingüismo literário, em Cabo Verde, afirma que não se poderá “contrariar o processo de desenvolvimento duma literatura de língua portuguesa", mesmo porque os movimentos de libertação africana aceitaram a língua portuguesa como oficial. Em se tratando do estrato literário, há substanciais transformações não só em Cabo Verde, como nos outros países africanos de língua portuguesa. Há, assim, diz ele, "uma mestiçagem lingüística, não só na estrutura fonética como na morfológica, incorporando inovações formais no plano da sintaxe, numa permanente e irreversível desagregação das língua-padrão."

Enfim, todos os que responderam à questão proposta por Jacinto do Prado Coelho, quer encarando o problema do ponto de vista lingüístico, quer, do ponto de vista sociocultural, destacaram que a língua portuguesa, por uma razão ou outra, será a língua literária das cinco nações africanas. 
R.V.A. - Por várias características climáticas e sociais do arquipélago - como a seca e a falta de opções de trabalho - o Exílio parece ser um dos temas mais latentes àquela literatura. Outro tema recorrente, que aparece desde o conto fundador "Galo cantou na Baía" de Manuel Lopes, é o que refere a morna como gênero musical e a relação literatura e música que daí decorre, com menções tanto às canções como a seus compositores em diversas obras. É procedente esta nossa percepção?

Sim, é procedente. Em meu livro Percursos pela África e por Macau ${ }^{29}$, dentre os textos a respeito de Cabo Verde, dois versam sobre esses temas: "Cabo Verde: o drama da partida em sua literatura" e "Morna - expressão de lirismo cabo-verdiano".

A emigração tem sido um dos tópicos da literatura de Cabo Verde, desde os anos de 1930. Eugênio Tavares (1867-1930) foi quem glosou pela primeira vez o drama da partida no poema-morna "Hora di Bai". Ouçamo-lo:
$[\ldots]$
Hora di bai, Hora da partida
Hora di dor! Hora de dor!
Amor, Amor,
Dixa' n chorâ! Deixa-me chorar!
Corpo catibo, Corpo cativo,
Bá bo que é escrabo! Vai tu que és escravo!
Ó alma bibo, Oh alma viva,
Quem que al lebabo? Quem te há-de levar?)

Jorge Barbosa, um dos mentores do movimento que culminou em Claridade (1936), já havia publicado Arquipélago, em que retratava a tragédia das secas pelas constantes estiagens.

Pedro Corsino Azevedo (1905-1942) enfatiza o trabalho escravo do emigrante, em imagens de densa conotação dramática, como se pode conferir em versos de seu poema "Terra-Longe", publicado em Claridade n 4. Distante

29 CANIATO, Benilde Justo. "Cabo Verde: o drama da partida em sua literatura”. .Percursos pela África e por Macau. Cotia (SP), Ateliê Editorial, 2005, p. 47-59. 
das realidades sonhadas, ainda menino, supõe a mãe a embalá-lo e a lhe dar conselhos:

"Ai, não montes tal cavalinho,

Tal cavalinho vai terra-longe,

Terra-longe tem gente-gentio,

Gente-gentio come gente."

$[\ldots]$

Depois vieram os anos,

E, com eles, tantas saudades!...

Hoje, lá no fundo, gritam! Vai!

Mas a voz da minha mãe,

A gemer de mansinho

Cantigas da minha infância,

Aconselha ao filho amado:

"Terra-longe tem gente-gentio,

Gente-gentio come gente."

Terra-longe! Terra-longe!..

- Oh mãe que me embalaste!

- Oh meu querer bipartido! ${ }^{30}$

Osvaldo Alcântara, pseudônimo poético de Baltasar Lopes, em Romanceiro de São Tomé (1958), compõe oito poemas em torno do exílio de cabo-verdianos que vão para as roças de café e cacau na "terra-longe". A presença do mar e as terras estéreis convidam o cabo-verdiano para a evasão, passando a refletir também a fuga dos intelectuais para outras terras. Assim, à maneira de Manuel Bandeira, Osvaldo Alcântara emigra para Pasárgada a representar "o paradigma de conquista última pelo homem", como diria Manuel Ferreira:

Saudade fina de Pasárgada...

Em Pasárgada eu saberia

30 FERREIRA, Manuel. No reino de Calibã 1. Lisboa, Seara Nova, 1975, p. 119-120. 
Onde é que Deus tinha depositado

$\mathrm{O}$ meu destino...

O evasionismo não deve ser pensado como fuga, alerta Manuel Ferreira. Assim, o sujeito poético, transportado para outras terras, reconhecia a estreiteza de suas ilhas, na medida em que a situação colonial levava os jovens poetas a protestos, a interrogações, a evadir-se para outras civilizações. Seria, "fuga à erosão colonial" e não "voltar as costas à cabo-verdianidade"31.

Posteriormente, Pasárgada passa a ser o símbolo da solução elitista dos problemas de Cabo Verde, como se pode conferir pelo clamor poético de Ovídio Martins, em seu poema "Anti-evasão", publicado em Caminhada, em 1962. A partir da súplica da primeira estrofe, o poeta chega à ação veemente da última:

Pedirei

Suplicarei

Chorarei

Não vou para Pasárgada

Atirar-me-ei ao chão

E prenderei nas mãos convulsas

Ervas e pedras de sangue

Não vou para Pasárgada

Gritarei

Berrarei

Matarei

Não vou para Pasárgada

Outros poetas anti-pasargadistas inspiraram-se na emigração para São Tomé, como: Onésimo Silveira em "Poema”, Gabriel Mariano em "Caminho longe" e Corsino Fortes, em "Emigrante".

A prosa narrativa percorre o mesmo caminho do movimento cultural da poesia. Chiquinho, de Baltasar Lopes, terá como elemento catalisador a emi-

31 O discurso no percurso africano I. Lisboa, Plátano, 1989, p. 160. 
gração para a América do Norte, emigração livre, promessa feliz de regresso à terra natal, certamente.

Manuel Lopes, em Chuva Brava (1956), evidencia de forma dramática o dilema entre partir e ficar. Enquanto algumas personagens decidem emigrar para o Brasil, outras decidem ficar, como o protagonista Mané Quim, quando acorda com o barulho da chuva.

Os emigrantes têm sido atraídos por vários pontos distantes do seu Arquipélago. São Tomé, ilha do golfo da Guiné, é para eles a "terra-longe”, significando trabalho escravo, sofrido e penoso. Em Hora di Bai, de Manuel Ferreira, a ilha é sempre um "negócio da China" para o engajador de Cabo Verde e para o dono das roças da "terra-longe", que tem "gente-gentio", como já dissera o poeta Pedro Corsino.

Em Voz de Prisão (1971), também de Manuel Ferreira, São Vicente e Lisboa representam os pólos da (e)migração e do retorno. Joja, figura feminina, destaca-se em seu "papiamento", recordando-se de Cabo Verde, pois "é nhá terra, nossa terra é pequenina, mas terrinha de saudade". Foi para Lisboa com objetivo de casar as filhas e formar o filho em medicina, porém Cabo Verde foi com ela, mantendo-a em sua inteireza pela memória.

Em Cais-do-Sodré-te-Salamansa (1974), livro de contos de Orlanda Amarílis, há personagens que vivem em Lisboa, recordando-se, com nostalgia da vida do Arquipélago. Seus reencontros e desencontros em Cais-do-Sodré (Lisboa), ou em Salamansa (São Vicente), marcam-se por vozes integradas na "morabeza" de Cabo Verde. Simbolicamente, a partida e a chegada abrem e encerram o livro. Em Ilhéu de Pássaros (1983), Amarílis aborda a fome, a seca e os ventos como temas recorrentes. Suas personagens, ainda que movidas pela necessidade de partir para fugir da terra "nhanhida", nunca a perdem de vista, mantendo suas raízes sempre vivas. O "ilhéu dos pássaros", que dá nome ao livro, serve de símbolo como "farol-guia" da memória.

R.V.A. - Ainda sobre a constante referência às mornas em obras literárias cabo-verdianas. Poderia falar-nos um pouco mais sobre sua origem e características? 
Poesia, música e dança, a morna reflete a "morabeza", o sonho e o sofrimento contido do povo de Cabo Verde, diante de suas adversidades. Sua gênese perde-se no tempo em que se dá a aculturação de seu povo ${ }^{32}$.

Para Eugênio Tavares, a origem da morna estaria na ilha de Boa Vista, passando depois para as outras ilhas, "adaptando-se, e tomando a feição psíquica de cada povo, como que num gráfico de ascensão ou descensão em sua expressão artística”. Aperfeiçoou-se em São Vicente como música. E na ilha Brava, onde os homens casam com o mar, "a morna fixou os olhos no mar e no espaço azul, e adquiriu uma linha sentimental, essa doçura que caracteriza as canções bravenses" "33.

Sabe-se que no século XIX, a morna já era cantada e dançada no Arquipélago. Por seu caráter dolente e nostálgico, é possível que tenha recebido alguma influência dos lamentos árabes marroquinos. Ou, então, segundo Luís Romano, teria sido "gerada pela melancolia que humanamente prevaleceu nos núcleos dos primeiros elementos, que chegaram do Reino"34.

A morna "Brada-Maria!", originária da ilha de Boa Vista, segundo Eugênio Tavares, seria a morna mais antiga. Conta a história de uma jovem "desviada de seus deveres", que, após ter sido abandonada, grita a sua dor pelos desvãos da madrugada. Um velho sacristão recolhe-a, chora com ela, e depois a conduz ao lar, onde é recebida de braços abertos pela mãe. "Lancinante grito duma caída”, Brada-Maria! É ouvida sempre com lágrimas ${ }^{35}$.

Como solução catártica de um povo sofrido, a morna faculta a liberação dos sonhos, expressando os acontecimentos do dia-a-dia. Nos bailes atinge a sua maior expressão, como mensageira do "crechéu", da "morabeza" e da saudade.

Sobre o tema da morna, há também "O galo cantou na baía", conto de Manuel Lopes, ao qual vocês fizeram referência. Destaca-se como personagem o guarda Tói: "mornador brabo, e as mornas que inventava eram dançadas e

32 CANIATO, Benilde Justo. "Morna - expressão de lirismo cabo-verdiano". Percursos pela Africa e por Macau. Cotia (SP), Ateliê Editorial, 2005, p. 71-76.

33 TAVARES, Eugênio. "Prefácio do autor: A morna e o povo de Cabo Verde". Mornas - cantigas crioulas. Lisboa, J. Rodrigues \& Cia., 1932.

34 "Cabo Verde - Renascença de uma civilização no Atlântico Médio". Ocidente. Lisboa, LXXIII (353), 1967, p. 144.

35 TAVARES, Eugênio, ibidem. 
cantadas com entusiasmo nos bailes nacionais, menos de uma semana depois de nascidas" $" 36$.

R.V.A. - A seca e a fome são também temas recorrentes da literatura caboverdiana. A senhora realizou estudos sobre estes tópicos?

Em artigo da revista Veredas, desenvolvi tal tema. Segundo António Carreira, a seca e a fome persistem nas ilhas de Cabo Verde desde que foram descobertas37. Segundo ele, a primeira da qual se tem registro prolongou-se de 1580 a 1583. Muitos morreram de fome e outros emigraram para os "rios da Guiné". O autor registra outras crises ao longo dos séculos XVII, XVIII e XIX. Neste, entre 1809 e 1811, uma grande fome na ilha de Boa Vista dizimou muita gente e animais domésticos.

Nas crises do século XX, Carreira destaca a de 1921-1922, em que o povo se achou no "último estágio de miséria nua", por ter consumido roupas, terras e jóias, acrescido por um obituário de mais de 23 mil pessoas. Também a crise de 1941-1943 registrou uma mortalidade de mais de 24 mil pessoas. E na de 1947-1948 houve tantas deslocações de famintos que foi impossível controlar o obituário ${ }^{38}$.

Além das secas há também pragas de depredadores, gafanhotos, lagartas de várias espécies, ratos e outros, danificando pastagens e culturas, ta necessárias para o povo mitigar a fome.

No "Prefácio" de seu livro de contos Terra trazida, Manuel Ferreira considera que o cabo-verdiano resiste se houver milho, feijão e leite. Com a escassez das chuvas, desaparecendo a cabra, ele ainda consegue subsistir com o milho e o feijão, a "cachupa pobre". Restando milho apenas e pouco, instala-se a tragédia da fome:

Fome oculta, fome crônica, fome epidérmica, fome total. A boqueira, o beribéri, a caquexia, o inchaço, a pelagra larvando. A pelagra na sua destruição dos três

36 Galo cantou na baía e outros contos. Lisboa, Caminho, 1998, p. 15.

37 “Cabo Verde - A fome em sua literatura". Em Veredas. Porto Alegre, EDIPUCRS, 2007, p. 131-144. 38 CARREIRA, António. Cabo Verde (Aspectos sociais: secas e fomes do século XX). Lisboa, Ulmeio, 1984. 
dd: dermatose, diarréia, demência. E nesta dura caminhada, nesta longa odisséia, dezenas de milhar caídos de more morrida, morte matada39.

Até os anos 20 do século passado, os escritores cabo-verdianos não se tinham dado conta do que poderiam fazer por sua terra. Foi a partir da publicação de Diário (1929) que António Pedro, surpreendendo-se com a situação de sua ilha natal, Santiago, registrou em seus poemas as inquietações pelos dramas da "terra queimada”, da "terra seca”, pois "Cá há mais do que calor,/ há dor/ do sol!"”

Mas a partir da revista Claridade (1936) foram assinaladas expressões de revolta contra o drama do Arquipélago, numa espécie de pré-nacionalismo que revelava a realidade insular. Para Teixeira de Sousa, com Claridade fez-se luz na literatura cabo-verdiana, afastada até aquele momento de seus valores culturais $^{40}$.

Poetas como Osvaldo Alcântara, Manuel Lopes, Aguinaldo Fonseca, Ovídio Martins, Mário Fonseca, Gabriel Mariano e tantos outros, ao extrair das imagens que se repetem, criam agentes de poetização lírica, meios necessários para que cada um deles possa compensar as agruras das terras secas de suas ilhas.

No longo poema épico "Capitão Ambrósio" (inédito), herói do povo, filho das ilhas, Gabriel Mariano dignifica as origens do cabo-verdiano. O poema, largamente divulgado em fita magnética entre os militantes da independência de Cabo Verde, suscita intensa dinamização, na medida em que configura o universo ficcional em seu contexto físico, moral e ideológico. Confiram-se os seguintes versos:
Bandeira
Negra bandeira
Bandeira negra da fome.
Em mãos famintas erguidas
Guiando os passos guiando
Nos olhos livres voando

39 Terra traziida. Lisboa, Plátano, 1972, p. 8.

40 "Da Claridade à Clarividência". Suplemento de A Semana 125. Cabo Verde, 18/0ut/1993. 
Voando livre e luzindo

Inquieta e livre luzindo

Luzindo a negra bandeira

Clara bandeira da fome.

[...]

Vaina frente o Ambrósio

Mulato Ambrósio guiando

Leva nas mãos a bandeira

Pesada e fria é a noite

Injusta e amarga é a fome ${ }^{41}$.

A abordagem da fome e da morte, principalmente quando resultam das secas, impregnam também mornas, coladeiras, finançons e batuques.

Na prosa Chiquinho (1947), de Baltasar Lopes, é destacada a fome impiedosa da ilha de São Nicolau, que crestara toda a plantação; Chuva brava (1956), de Manuel Lopes, põe em evidência a estiagem de Santo Antão, com todas as vicissitudes acarretadas por ela e Os flagelados do vento leste (1960), também deste autor, expressa os ventos e as secas a pesarem tragicamente sobre os destinos humanos.

Em Famintos (1962), de Luís Romano, a seca, com suas trágicas conseqüências é exacerbada por cenas cheias de realismo. Tendo por palco todas as ilhas do Arquipélago, atingidas e englobadas numa só - "Ilha sem Nome"-, o romance, alinhavado e compilado na década das grandes fomes dos anos 40, assinala, com ironia, o fato de as secas serem fonte de riqueza para os donos das roças de cacau.

Manuel Ferreira registra o espaço da seca de 1943 em seu romance Hora di bai (1962), como já foi mencionado:

A maldição varrera a ilha. A maldição da estiagem. Da fome. Os sobreviventes dessa fúria ciclônica, que eram? Restos de vida absurda e degradada na luta impiedosa pela sobrevivência ${ }^{42}$

41 ANDRADE, Mário. Antologia temática de poesia africana. Lisboa, Sá da Costa, p. 51.

42 Hora di bai. São Paulo. Ática, 1980, p. 18. 
Em Ilhéu de contenda (1978), Teixeira de Sousa constrói sua narrativa recriando o ambiente da ilha do Fogo, onde nasceu e passou sua juventude. A "lestada" de ar quente sopra rijo "açoutando árvores e culturas", enrodilhando folhas, ramos e pó. A verdura amanhece num emaranhado de hastes e folhas ardidas. O milharal derrubado no chão mistura-se com as aboboreiras e feijoeiros, como palha seca. Tudo queimado pelo vento leste! ${ }^{43}$

R.V.A. - Quais são os trabalhos acadêmicos sobre Cabo Verde que vêm sendo desenvolvidos sob a sua orientação atualmente?

Dentre os vários alunos que tenho tido na Área de Estudos Comparados de Literaturas de Língua Portuguesa, alguns se dedicaram ou se vêm dedicando à literatura de Cabo Verde. Alceu Leite Ribeiro apresentou a tese "Literaturas em contato: Brasil e Cabo Verde (análise de O Quinze e Chiquinho)”, em 2005. Antonio Aparecido Mantovani e Susanne Maria Castrilon da Silva estão com seus projetos de tese em andamento. E Suely Alves de Carlos vem desenvolvendo seu projeto de dissertação de mestrado. A seguir, apresento um breve resumo de seus trabalhos.

1. Alceu Leite Ribeiro - Tese defendida em maio de 2005: "Literaturas em contato: Brasil e Cabo Verde (análise de O Quinze e Chiquinho)".

Em seu trabalho, Alceu procurou mostrar o caminho escolhido por Rachel de Queiroz em O Quinze e por Baltasar Lopes, em Chiquinho, quando utilizam ora a linguagem culta ou padrão, ora a linguagem popular ou coloquial, de acordo com o retrato das personagens que querem apresentar ou os momentos de maior ou menor emoção, para indicar níveis culturais e sociais. Destaca que a linguagem culta ou padrão demonstra maior formalidade, enquanto a linguagem popular ou coloquial, menor formalidade, em momentos de alta tensão emotiva, principalmente nos diálogos como a melhor forma de criar o espaço dramático.

O autor de Chiquinho foi precursor, quando utilizou o poder da oralidade como instrumento de comunicação, elaborando uma síntese lingüística de que participam a língua cabo-verdiana falada e a portuguesa falada e escrita. Cria, assim, um novo falar que é uma adaptação dos falares português e cabo- 
verdiano, oferecendo-nos, como resultado, uma língua literária nova, de grande poder expressivo e significativo, adaptada às necessidades do novo universo.

A escolha praticada tanto por Rachel de Queiroz como por Baltasar Lopes tem sempre dois caminhos: o valor semântico dos vocábulos e sua carga emotiva, criando-se, dessa maneira, um novo espaço literário consciente e definidor do que ambos pretendem: mostrar uma trágica realidade social que é a seca, a miséria, o sofrimento moral de dois povos que aparecem retratados pelo poder da linguagem. Cria-se para isso um léxico especial carregado de abundantes conotações metafóricas e simbólicas com um registro discursivo embalador de acordo com o lirismo de Chiquinho apaixonado por Nuninha ou de Conceição, com seu amor completamente indefinido por Vicente.

A linguagem coloquial ocorre em um texto literário em função da necessidade de oferecer um maior potencial lírico e poético, podendo-se constituir verdadeiro dicionário de termos e expressões, de efeitos sugestivos muito fortes que aparecem no texto, principalmente, por meio das falas do narrador e das personagens. Predominam quase sempre os estratos populares que são aqueles que apresentam maior criatividade lingüística

2. Antonio Aparecido Mantovani - Projeto de tese em andamento

Titulo provisório: Os Dois Irmãos, de Germano Almeida e Dois Irmãos, de Milton Hatoum: o tema dos irmãos e o drama familiar pela influência do meio e o espaço representando a ruína.

O diálogo entre a literatura brasileira e a cabo-verdiana não se esgota nas décadas de 30 e 40, podendo ser observado até a atualidade e também em outras regiões além do Nordeste brasileiro. A partir desta reflexão, este estudo tem como objetivo investigar as relações literárias contemporâneas entre Brasil e Cabo Verde dentro do macrossistema literário de língua portuguesa, especificamente com as obras acima citadas. São obras que se aproximam em virtude de alguns fatores como a hibridez cultural, a emigração, a influência dos valores da sociedade, o tema do duplo e dos irmãos e o drama familiar por causa do adultério e da vingança. Os ambientes influem determinando o comportamento das personagens que, não raro, são movidas pelo contexto em que estão inseridas.

3. SusanneMaria Castrilon da Silva - Projeto de tese em andamento

Título provisório: A escravidão em $O$ Escravo, A Escrava Isaura e Os tambores de São Luís. 
O projeto propõe definir como a temática da escravidão tem sido projetada de forma distinta nas produções escritas de língua portuguesa. Em Cabo Verde, José Evaristo de Almeida publica O Escravo, e no Brasil, Bernardo Guimarães e Josué Montello produzem, respectivamente, A Escrava Isaura e Os Tambores de São Luis. O objetivo da tese é estabelecer parâmetros comparativos que nortearam os olhares para a escravidão africana e brasileira, permitindo perceber como a arte a recria: ora pelo viés das culturas atávicas que, legitimando e expandindo num espaço que se sobrepõe àquele com que se imbricam autoritárias e dominadoras, oferecem continuidade ao mito fundador e excluem os colonizados; ora pelo viés das culturas compósitas, formadas por elementos díspares, abertas ao contato com outras culturas, mostrando-se dispostas a mesclar sem o mito fundador. Como parâmetro analítico, destacam-se a ênfase à escravidão e as séries de identidades ativadas a partir de relações e interações que se apóiam, em entendimentos de sistemas híbridos, em processos de deslocamentos e rupturas de concepções fixas e dominadoras.

4. Suely Alves de Carlos - Projeto de dissertação em andamento.

Título provisório: Diáspora e identidade cultural em Orlanda Amarílis e Clarice Lispector.

O projeto objetiva analisar a identidade cultural e a diáspora no mundo globalizado e seus conseqüentes conflitos nos contos Thonon-les-Bains, Desencanto e Cais-do-Sodré te Salamansa, de Orlanda Amarílis, e no romance A hora da estrela, de Clarice Lispector.

Nos contos de Orlanda Amarílis, as personagens femininas, jovens caboverdianas, ainda que inseridas num contexto cosmopolita europeu, permanecem ligadas às ilhas. Evidencia-se, dessa forma, a memória como alternativa encontrada por Orlanda Amarilis para impedir que, em função da acentuada migração, a cultura insular se perca.

Em A hora da estrela, a personagem Macabéa, vivendo no Rio de Janeiro, vai identificar-se com outro nordestino num encontro de sobreviventes da mesma sina, mas não traz lembranças; não se lembra nem dos pais, portanto, tem apenas retalhos de sua identidade.

É nesse contexto de semelhanças e dessemelhanças entre personagens tão próximas e ao mesmo tempo distantes que a pesquisa será aprofundada. Também mostrar que na pós-modernidade há uma ausência de identidade fixa, essencial e permanente. 
R.V.A. - O que ainda resta inexplorado e seria interessante estudar na literatura cabo-verdiana?

Há muito que pesquisar sobre sua literatura. Sobre o século XIX: O Boletim Oficial (1842) que traz comentários sobre literatura. Também a Revista de Cabo Verde (1899) que comenta a literatura em alguns textos e o Almanaque Luso-Africano do cônego Antônio Manuel da Costa Teixeira, cujas historietas, anedotas, lendas, poesia e letras de canções valem a pena ser pesquisadas. E poetas como Antónia Gertrudes Pusich (1805-1883), Henrique de Vasconcelos (1875-1924), António Januário Leite (1865-1930). A literatura da 1ª metade do século XX também merece ser pesquisada.

Sobre a literatura, após a independência, Germano de Almeida já tem um acervo respeitável de obras publicadas, a partir de O testamento do Sr. Napumoceno da Silva Araújo, de 1991. Poetisas, como Vera Duarte e Maria Helena de Morais Sato.

R.V.A. - Qual o seu conselho ao estudante que pensa em começar hoje um trabalho sobre Cabo Verde? Gostaríamos que indicasse, também, um roteiro mínimo de obras literárias para se ter uma boa idéia do conjunto da literatura de Cabo Verde.

Iniciar por um estudo da história das ilhas, objetivando adentrar-se nos temas recorrentes de sua literatura. A obra Aventura crioula, de Manuel Ferreira, por ser um ensaio acurado de antropologia, sociologia, língua e história literária de Cabo Verde, parece-me indispensável para dar ao aluno uma visão abrangente sobre o Arquipélago. Há nessa obra uma exaustiva bibliografia, que servirá de instrumento de trabalho muito bom para os iniciantes.

\section{Roteiro de obras literárias:}

ALMEIDA, Germano. O testamento do Sr. Napumoceno. São Paulo: Cia. das Letras, 1996.

Os Dois Irmãos. $2^{\mathrm{a}}$ ed. Lisboa: Caminho, 1995.

AMARÍLIS, Orlanda. Cais-do-Sodré té Salamansa. Coimbra: Centelha, 1974.

FERREIRA, Manuel. Terra Trazida. Lisboa: Plátano, 1972. 
- Aventura crioula. Lisboa: Plátano, 1973.

Hora di Bai. São Paulo: Ática, 1980.

LOPES, Baltasar. Chiquinho. São Paulo: Ática, 1986.

LOPES, Manuel. Galo Cantou na Baía. $2^{a}$ ed. Lisboa: Caminho, 1998.

Chuva Braba. Lisboa: Caminho, 1997.

ROMANO, Luís. Ilha. Mindelo (Cabo Verde): Ilhéu ed., 1991.

SATO, Maria Helena de Morais. Areias e Ramas. São Paulo: Subíaco, 2006.

TAVARES, Eugênio. Mornas, Cantigas Crioulas. Lisboa: J. Rodriguess \& Cia., 1932.

TEIXEIRA de SOUSA. Henrique. Ilhéu de Contenda. Lisboa, São Paulo:

Ática, 1984.

. Contra mar e vento. Lisboa: Prelo, 1972. 